\title{
Reference and meaning: the ambiguity of definite descriptions in wills
}

\author{
by Ross Charnock
}

This is the first of two articles adapted from a lecture given to the Statute Law Society at the Institute of Advanced Legal Studies on October 1, 2007. The second article will look at the use of general terms and reference to natural kinds.

\section{INTRODUCTION}

I $\mathrm{t}$ is often assumed, following the traditional, "common sense" view, that words have fixed, literal meanings, which can be defined independently of the context of use. Judges tend to make similar assumptions. Although they aim to give effect to the intention of the legislature, the contractor or the testator, they have good reasons to avoid pragmatic interpretation, which may lead to case-bycase interpretation in which they would no longer be following a rule at all. They claim instead to collect the intention from the words used. Unfortunately, this cannot be possible. It is a basic principle of linguistic pragmatics that, since the context always affects understanding, the communicative intention cannot be identical with the purely semantic sense of the words.

On closer inspection the idea of a "true and correct" literal meaning turns out to be a layman's illusion, which does not even account for the natural use of substantive terms, which do not simply denote substances. Even reference to individuals, using proper names and definite descriptions, must depend to some extent on the speaker's intention in context.

\section{Reference to individuals}

If the function of names or definite descriptions was simply to denote the relevant individuals, then expressions which fail to refer, that is, those to which no referent corresponds, would have no meaning. Yet it seems obvious that, if "Excalibur" is the name of an object, it should not cease to have meaning when the object is broken into pieces (Wittgenstein 1953, para 40). If the meaning of referential expressions depended on the existence of the relevant individual, it would not be possible to refer to imaginary, non existent or fictional characters. Common expressions like "Harry Potter" or "the baby we never had" would have to be classed as meaningless. Statements claiming, uncontroversially, that "Harry Potter does not exist" would then appear as paradoxical (if true, they would be meaningless, and if meaningful, they would be false). Furthermore, statements of identity, where different names or definite descriptions relate to the same individual, would be simple tautologies. Thus to say that "Brett MR is Lord Esher" or "William Murray is Lord Mansfield" would be to say no more than "Brett is Brett", or "Murray is Murray". Similarly with definite descriptions, as to enquire whether "Gordon Brown is the present PM", or indeed whether "Scott is the author of Waverley' (Russell, “On denoting”, Mind 1905), would be simply to ask whether 'Brown' was Brown or 'Scott' was Scott. Frege's solution to this problem ("Sinn und Bedeutung", 1892) was to distinguish between the meaning and the denotation. However, this has the unfortunate effect of presenting the "meaning" as a private, purely mental entity rather than as a public property which could be grasped and communicated by different speakers.

Nor is it possible to understand proper names as standing for an exhaustive set of descriptions, as then the meaning would then vary according to different speakers' knowledge or interests. This problem was clearly pointed out by Wittgenstein ("Philosophical Investigations", 1953):

"We may say, following Russell: the name 'Moses' can be defined by means of various descriptions. For example, as 'the man who led the Israelites through the wilderness', 'the man who lived at that time and place and was then called 'Moses'. [...] And according as we assume one definition or another the proposition 'Moses did not exist' acquires a different sense, and so does every other proposition about Moses."

(Philosophical Investigations, Oxford: Blackwell, para 79) 
Although the question of the meaning of names has long been a subject of philosophical debate, few genuine problems arise in practice either in ordinary conversation or in the interpretation of wills. Where names are misused in wills, the problems raised are usually restricted to the question of identification.

Testatators are occasionally mistaken regarding the names of the objects of their generosity. The existence of the Latin maxim veritas demonstrationis tollit errorem nominis leads us to suppose that such difficulties were not unknown to Roman lawyers. But the problems raised usually concern the identity of the beneficiary rather than the more complex question of the meaning of his or her name.

In Re Smalley (Smalley v Scotton) (1929) 73 Sol Jo 234, CA, the testator left a gift to "my wife Eliza Ann Smalley." His wife's name was in fact Mary Ann. He had left her to live with Eliza Ann Mercer, the widow of a publican. The court, required to discover the intention of the testator, and unwilling to suppose that he had intentionally made a meaningless will, admitted evidence to show that during the latter part of his life, the testator did habitually use the word "wife" as implying Eliza Ann Mercer. Hanworth MR held that the name was less important than the definite description: "The word 'Smalley' added to the words 'Eliza Ann' meant nothing at all, because it was simply linked with the word 'wife'."

In NSPCC ${ }_{V}$ SNSPCC [1915] AC 207, it was claimed that a Scottish testator who had left $£ 500$ to the National Society for the Prevention of Cruelty to Children really meant to leave the money to the equivalent Scottish society. Again, the problem was one of identification rather than meaning. The Scottish court thought the money should remain in Scotland, but the House of Lords decided unanimously that, as the two societies had the same aims, it was unnecessary to create such an unfortunate precedent. The gift therefore went to the London society, the unspoken assumption being that, as the two Societies had similar aims, the testator was unlikely to object.

\section{The presupposition of existence}

For Russell (1905), the successful use of names must depend on the existence of the individual referred to. Definite descriptions are also said to presuppose the existence of the referent. Where the presupposition fails, as in "The present King of France", the expression cannot be said to be either true or false. It must therefore be meaningless. The view now appears as an oversimplification.

On the linguistic level, Strawson showed ("On Referring", 1950) that a sentence like "Among the people I met yesterday was the present King of France" could be seen as false, rather than meaningless. More generally, this seems to be the case where the definite description figures in the predicate rather than as the subject of the sentence. Strawson's solution was to propose a more pragmatic definition of presupposition. On the new view, speakers, and not linguistic expressions are said to refer. Thus reference "is something that someone can use an expression to do." This means that interpretation must depend on the communicative intention in context. Thus, contrary to judicial assumption, there can be no purely literal understanding.

To consider definite descriptions which fail to refer as systematically meaningless rather than false would also risk creating new legal problems. Misrepresentation would be hard to prove if a reference to a "Stradivarius violin of 1738 ", for example, was considered as referring to nothing at all, the maker having died the previous year. (It may also be difficult to secure a conviction for "breach of the peace", if the non existence of the "peace" was accepted as a defence.) Definite descriptions are often mistakenly used in wills; problems arise where the description fails to refer to the intended individual.

In Wagstaff [1908] 1 Ch 162, for example, a testator left the use of his house to: "My dear wife, D J Wagstaff ; if she shall so long continue my widow, for her own use and benefit, and upon her decease or second marriage, then over." However, although he had gone through a marriage ceremony with her in 1884 , the lady in question was never truly his wife, and could not therefore be his widow. She was in fact already married to one A G Jalland, who was still living. The definite description therefore had no referent, and should be considered meaningless. Kekewich J considered this possibility, but preferred to rely on what he called a "secondary" meaning:

"I must find some way out of it. I am not at liberty to say that he meant nothing. If he does use the word 'widow' in a secondary sense, my duty is to find out what is the secondary sense.” (Re Wagstaff ChD 1905, per Kekewich J)

Kekewich J's judgment was confirmed on appeal by Cozens-Hardy MR, who gave more importance to the name than to the (false) description:

\footnotetext{
"The testator first of all gives certain furniture and effects to 'my dear wife, Dorothy Josephine Wagstaff, for her own absolute use and benefit.' Now there is not a moment's doubt as to who is meant by that. The testator means beyond all doubt, and it has not been disputed, the lady with whom he went through the form of marriage at St. George's, Hanover Square." (CA, Cozens-Hardy MR)
}

\section{THE CAUSAL THEORY OF REFERENCE}

The fact that referential expressions usually function unproblematically suggests that a theory which predicts unavoidable metaphysical difficulties is probably inadequate. Kripke ("Naming and necessity," 1972) proposes a more realistic theory, in which the use of proper names is seen as a kind of linguistic practice (in the sense of Wittgenstein, 1953), depending ultimately on a kind of original baptism. In this theory, reference depends 
neither on facts in the real world, nor on individual perceptions, but rather on shared beliefs in the linguistic community. Names are associated with characteristics which are neither necessary, nor analytic. The name will therefore continue to function even where particular beliefs are abandoned.

According to the causal theory, names continue to refer to the relevant individual, even where no information is available apart from the name itself. Aldous Huxley pointed out the circularity involved in this approach, with the somewhat paradoxical aphorism: "The author of the Iliad is either Homer or, if not Homer, somebody else of the same name." Yet in spite of the apparently fragile basis, the theory still seems intuitively satisfactory. Everyone understands references to the Biblical character of Jonah, for example, even though nothing supposedly known about him is in fact true. A more contemporary case is observed in one of the "Dud and Pete" dialogues, in which they discuss the situation of one "Roger Braintree", unknown to either of them. Their conversation was based on a name found in the telephone directory.

The causal theory thus shows how proper names can unproblematically denote particular individuals even in conditions of imperfect knowledge. However, it is a consequence of the theory that definite descriptions do not function in the same way. Instead, they take their sense from the description given.

\section{Rigid reference and ambiguity}

Kripke's causal theory predicts that while proper names refer rigidly to the same individual in all possible worlds, definite descriptions will appear ambiguous in modal contexts.

This distinction may be illustrated as follows. Although "Gordon Brown" and "the present Prime Minister" refer to the same individual, the sentences "Gordon Brown could have been English" and "the present PM could have been English" are not synonymous. The former evokes a possible world in which the same individual was born south of the border. But the latter has (at least) a second possible reading. While it may evoke the same possible world in which Gordon Brown was born south of the border, it may also evokes another possible world in which a different individual, an Englishman, could have been elected to the post of Prime Minister. The same is true for sentences like: "The PM could have been a Conservative" (though this last example would have been more plausible with 'Tony Blair').

This distinction between proper names and definite descriptions is an obvious exception to the substitution principle stated by Kant, according to which, if two expressions denote the same referent, it should be possible to substitute one expression for the other without changing the truth value of the sentence. Similar exceptions are seen with the de dicto/de facto distinction, which appears with verbs of propositional attitude. As few people are omniscient, some may not be aware of the recent change of Prime Minister. It is quite possible for such people to believe that the present PM is English, without necessarily believing the same thing of Gordon Brown. This distinction is accounted for by philosophers like Quine in terms of opacity ("Quantifiers and propositional attitudes", 1956). He gives the example: "Ralph believes that someone is a spy" which has several possible interpretations, including (i) there is at least one spy, and (ii) someone in particular is a spy. Everyone believes (i), but there may be disagreement over (ii).

It is sometimes tempting to attempt to apply the idea of rigid reference to legal terms, in order to define the "true and correct" meaning of concepts like "cruelty" in the context of "cruel and unusual punishments." Unfortunately, such attempts must fail, if only because "cruelty" is an abstract expression, rather than a substantive term, and cannot be said to refer to anything in the external world.

\section{THE REFERENTIAL / ATTRIBUTIVE DISTINCTION}

Donnellan showed, in "Reference and definite description" (1965), that definite descriptions are also ambiguous between their referential and attributive uses. This means that they may still refer to particular individuals, even where no individual corresponds to the given description. His example is: "Smith's murderer is insane."

In referring to "Smith's murderer," the speaker may have intended to refer to Jones, perhaps because Jones has been arrested and charged. Of course, as Jones has not yet been found guilty, he should not technically be considered a murderer. But in ordinary conversation, those who are similarly aware of legal developments will probably grasp the speaker's communicative intention, even if they do not agree that Jones is likely to be found guilty. Indeed, as Donnellan points out, even if we later discover that Smith committed suicide, and that no murder has in fact been committed, the speaker may still be understood as having intended to refer to Jones. Thus: "using the definite description referentially, the speaker may have said something true even though the description correctly applies to nothing." This is the referential use. In this sense: "there is a right thing to be picked out by the audience and its being the right thing is not simply a function of its fitting the description."

However, if the speaker has no idea who the murderer is, then, although he uses the same expression, he will not be understood as referring to anyone in particular. The expression no longer denotes Jones, but applies to whoever turns out to fulfil the description. This is the attributive use.

It should be noted that the correct interpretation of the definite description can only be discovered by pragmatic interpretation in context. It no longer depends on the 
literal meaning of the words. Donnellan himself points out that the communicative intention cannot be discovered by the application of any linguistic rule:

"It does not seem possible to say categorically of a definite description in a particular sentence that it is a referring expression [...]. In general, whether or not a definite description is used referentially or attributively is a function of the speaker's intentions in a particular case. [...] It does not appear plausible to account for this, either, as an ambiguity in the sentence (neither syntactic nor semantic - perhaps pragmatically).” (Donnellan 1966: 373)

Predictably enough, the failure of literal interpretation is a source of difficulty in legal interpretation.

\section{Referential and attributive interpretations in wills}

It would no doubt be difficult to draft a will allowing someone to inherit on the basis that he was a murderer, especially if the supposed victim had in fact committed suicide. Nevertheless, the referential / attributive distinction is frequently a source of ambiguity in wills.

In Re Whorwood (1887) 34 Ch D 446, a valuable silver cup was left to Lord Sherborne: "To Lord Sherborne and his heirs my 'Oliver Cromwell' cup presented to our common ancestor, Dame Ursula Whorwood, for an heirloom." Lord Shelborne died, to the knowledge of the testator, before the last codicil was added to the will. The linguistic problem arose because the eldest son automatically acceded to his father's title. The court had to decide whether the new Lord Shelborne should inherit. Internal evidence suggested that the bequest was probably intended attributively, that is to whoever fulfilled the given description at the appropriate time. References to all the other beneficiaries included the first name. It was also explicitly stated that the cup was intended as an heirloom. Yet the court refused the attributive interpretation, insisting that the bequest must have been made referentially. The reasoning, such as it is, was given as follows:

"At the time the will was made there was no doubt as to who was Lord Sherborne. There was only one person entitled to that appellation. Nobody could have had any hesitation in saying who Lord Sherborne was. No doubt the bequest did contain terms that shewed the testator intended that the cup should continue in the family of Lord Sherborne as an heirloom. But that fact does not alter the construction of the gift, which was intended for the then Lord Sherborne." (Re Whorwood, per North J)

This view was confirmed on appeal, the court again preferring to ignore the probable intention of the testator in order to preserve a supposedly literal interpretation of his words:

"The first question is whether the Court can admit evidence as to the intention of the testator. I am of opinion that it cannot do so. Evidence has been rightly admitted to shew that the testator knew at the time when he made his last codicil that the late Lord Sherborne was dead, but I do not think that fact has any effect at all upon the construction of this clause in the will. [...] If properly advised he would have drawn his will differently.” (Re Whorwood, per Cotton LJ)

This apparently perverse decision may possibly be explained pragmatically. As the testator had already left "all his silver and plated articles" to his "faithful friend and servant, Charles Rixon," it would only have raised new problems if Lord Sherborne had been allowed to take the cup.

In Re Boddington (1888), the definite description again failed to refer. The testator made his will on the mistaken assumption that he was married. The marriage was later declared void $a b$ initio for impotency. This amounts to a retrospective declaration that he had in fact never been married at all. He died without altering his will, leaving a gift of $£ 200$, and an annuity to be paid to his "said wife, so long as she shall continue my widow and unmarried." Regarding the gift, Fry J assumed that the definite description was intended referentially, and allowed the lady in question to inherit. But regarding the annuity, the same description was interpreted attributively, so that she could not take. His reasoning was as follows:

"It appears to me that the annuity is given to her for a period which can never come into existence. She never was the testator's widow, and therefore she can never continue his widow for any length of time. On principle, therefore, I am unable to see how an annuity for a non-existing period can possibly be claimed." (Re Boddington (1884) 25 Ch D 685 per Fry J)

This result was confirmed on appeal. Although the testator clearly intended one particular lady to benefit, the description he had given failed to refer to her. According to Lord Selborne:

"De facto she was his wife when the will was made, so there is no ground for imagining that he intended to do more than describe her as at that time she would be naturally and commonly described. But the annuity is given in terms which express a condition that she should continue his widow, and that the annuity should be paid only so long as she continued such, and we cannot depart from those words." (Re

Boddington 188425 CA 685, per Lord Selborne LC)

Cotton LJ, concurring, also insisted on different interpretations of the same definite description, regarding the gift and the annuity:

"In the case of the gift of the legacy to her qua wife there is only a falsa demonstratio; the description of wife being intended merely to point out the individual. That is not so and cannot be so as regards the reference to the widowhood. The reference to widowhood is not made merely to point out the person, but it is to point to that which will fix the duration, the beginning, and the ending of this annuity." (per Lord Cotton LJ) 
This was the authority followed by Farwell J when he refused to allow a "common law" wife to inherit in Re Gale [1941] Ch 209. Although the couple had lived as man and wife for an extended period, they had never in fact married. As the inheritance was not a gift but a benefit "during widowhood," Farwell J felt obliged to interpret the description attributively, rather than rely on the name given:

"The benefit given to her in respect of the house in Leeds is 'the use and enjoyment thereof during her widowhood' and that the payment of $£ 1$. 5s. per week is 'during her widowhood for a period of twelve years'. It is said that neither of those gifts can take effect because the period named in the will is 'during her widowhood'; and that that is a period which has never come into existence, she never having been married.” (Re Gale Ch D 1941, per Farwell J)

Similar problems occur with (unsurprising) frequency. In Re Amyot [1904] AC 268 the will referred to "the eldest son of my sister Frances McLean Gibney and his heirs for ever." The son in question predeceased the testator, and the question arose as to whether the surviving son should take. Lord MacNaghton refused, considering that there was no reason to suppose that the testator had not intended to use the description (referentially) to refer to an individual:

"There being then a person in existence at the time answering the description in the will, their Lordships are of opinion that that person, though he died afterwards in the testator's lifetime, was the object of the testator's bounty. There is nothing in the context to warrant any departure from the proper and ordinary meaning of the words employed." (Re Amyot 1904, per Lord MacNaghton)

It was pointed out that the single surviving son would not normally be referred to as "the eldest", but this overly grammatical approach was abandoned when it became apparent that even the deceased first son should more correctly have been described as "the elder" (of two sons). That objection was said to "savour of hypercriticism".

In Re Hickman's Will Trusts [1948] Ch 624 a necklace was left "to the wife of my grandson." At the date of death in 1914 , the grandson in question was still unmarried and so no individual answered the description. By the time of the hearing, however, Harman $\mathrm{J}$ was driven to describe the proceedings as a contest between two ladies, as the grandson had married and divorced Lilian Williams, and was already married again, to Dame Nancy Hickman. The judge again assumed that the testator intended to refer to an individual (on the dubious grounds that the necklace cannot have been meant to be "stretched round the collective neck of personal representatives). However, as he could not indulge in speculation as to the intention of the testatrix "if she had been able to foresee the future," he followed the principle suggested in Jarman on Wills:

"I think the principle must apply that the first person who answers the description of being the wife of the grandson is the one who takes the jewel and that there is nothing that can divest her of it”. (Re Hickman per Harman J)

In these latter cases, we observe a clear judicial preference for the referential interpretation, which appears to be adopted by default in cases of doubt in order to resolve any apparent ambiguity. However, the supposed "literal" meaning will always appear ambiguous, as the correct interpretation can only be decided in context. This means that it will be difficult to draft a will so as to impose the attributive interpretation. William Thompson managed nevertheless to make the attributive reading explicit. He intended to marry before going to sea as a sub-lieutenant in 1942, and found the time to make a will in favour of his future wife without referring to any potential partner in particular: "I, William Gilmour Thomson [...] do hereby in the event of my being married bequeath everything that I possess to my wife whoever she may be even if I leave children to be held under this will in trust."

He did marry, but was lost at sea only three months later. There were no problems about identifying his widow. However, the remaining provisions, concerning the valuation of the stocks and shares and the effect of remarriage, turned out to be so complex that the case was heard three times, in 1946, in 1955, and finally in 1969.

This form of words incidentally had the effect of imposing a future, rather than a present tense reading of the expression "may be", although this had been excluded in various earlier cases, regarding "any children who may be born" in wills, or indeed "houses which may be built" or "balance which may be due" in business agreements, as in Broom $v$ Batchelor (1856) $1 \mathrm{H} \& \mathrm{~N}$ 255. In that case, Pollock $\mathrm{CB}$ pointed out that the expression was frequently used in the Bible and in Shakespeare to refer to future events. However Bramwell B, dissenting, considered that the expression normally refers to the present, as in something which "may be black", or "fit to eat" or "fit to cook." This unsuccessful argument was based on the mistaken assumption that a literal meaning could be established, independently of the communicative intention in context.

\section{CONCLUSION}

When deciding cases, judges are obliged to take one interpretation as correct, thus by implication rejecting the others as unacceptable. Linguists, on the contrary, avoid making such judgments, and instead aim to describe the relations between the different possible meanings observed in context. They do not attempt to decide questions of grammaticality of interpretation independently of speakers' intuitions, but aim instead to account for these intuitions, which constitute the data to be explained. Whatever meaning appears in a given context is therefore accepted as the natural meaning in that context. Linguistic theory cannot therefore be expected to provide a justification for legal decisions. While there is a linguistic 
aspect to legal adjudication, there can be no question of replacing judges with linguists.

Legal scholars may nevertheless find an awareness of the main theoretical questions in linguistics useful. Even a basic knowledge of the linguistic metalanguage may facilitate discussion and reduce reliance on personal intuition.

The problem raised here principally concerns the nature of literal meaning, which is the subject of debate both in the field of semantics and in the law. Linguists agree that literal meaning cannot be observable, as all language necessarily occurs in some context. The contextualist philosophers go further, claiming that there can be no literal, or acontextual, meaning even at the most basic level. This view is corroborated to some extent by the observation that whenever literal meaning is mentioned in legal judgments, the judge finds himself unsure what to do. (Although this formulation may involve a certain confusion of cause and effect, the fact of the correlation remains).

Although (English) judges often claim to be basing their interpretation on the words used, they frequently accept what amounts in practice to a contextualist approach to the interpretation of wills. As purely literal interpretation cannot even account for reference to individuals, it has been accepted, at least since the judgment of James LJ in Boyes v Cook (1880) 28 WR 754, that in this field, the judge must place himself in the testator's armchair and consider the surrounding circumstances in order to discover his intention.

More generally, it is often admitted that linguistic usage depends not on objective definition but on agreement and shared knowledge within a particular community. In Doe $v$ Hiscocks (1839) 5 M\&W 363, for example, Lord Abinger suggested, albeit with some exaggeration, that within the testator's particular linguistic community, words may habitually be associated with meanings unavailable to outsiders. He therefore took all the facts and circumstances respecting persons or property to which the will relates as legitimate and necessary evidence for the understanding of the will.
"Again, the testator may have habitually called certain persons or things by peculiar names, by which they were not commonly known. If these names should occur in his will, they could only be explained and construed by the aid of evidence to shew the sense in which he used them, in like manner as if his will were written in cypher, or in a foreign language." (Doe v Hiscocks per Lord Abinger, cited by

Hanworth MR in Smalley [1929] 2 Ch 112).

This corresponds well with the observation that people use language differently in different contexts, for example, in social, professional and familial interactions. To this extent, we are all bi- or plurilingual.

This point is accepted and apparently taken for granted in Thorn $v$ Dickens [1906] WN 54, regarding the interpretation of what is still probably the shortest will ever to be held valid. The day before his death in 1905, the testator executed a document revoking his earlier will of 1896, containing only the three words "All for mother." The testator's mother could not inherit as she had not only predeceased the testator, but was already deceased at the date of the will. The court held that the testator had used the word "mother" to refer to his wife. Significantly, no argument or explanation is given. Instead, it is simply stated in the headnote that: "It was 'proved and admitted' that 'mother' meant the widow."

Contextual interpretation appears uncontroversial in wills regarding referential expressions. It may be expected to raise more difficult problems when the judge is required to determine the meaning of general terms in statutes, where expressions denoting natural kinds must be determined in contexts which may never have been envisaged by the legislature.

\section{Dr Ross Charnock}

Maître de Conférences at the University of Paris, specialising in the language of law. 